\title{
Protestivity and civic activism in youth: problems and contradictions
}

\author{
Irina V. Polozhentseva ${ }^{1 *}$, Galina N. Yulina ${ }^{2}$, Tat'yana L. Kashchenko ${ }^{3}$, and \\ Vitaly $V$. Kalita ${ }^{1}$ \\ ${ }^{1}$ K.G. Razumovsky Moscow State University of Technologies and Management (the First Cossack \\ University), Department of Pedagogy and Psychology of Professional Education, Moscow, Russia \\ ${ }^{2}$ K.G. Razumovsky Moscow State University of Technologies and Management (the First Cossack \\ University), Institute of Social and Humanitarian Technologies, Moscow, Russia \\ ${ }^{3}$ Financial University under the Government of the Russian Federation, Department of Political \\ Science, Moscow, Russia
}

\begin{abstract}
The present study combines a theoretical analysis of youth protest as a special social phenomenon and the results of an empirical study. Based on the empirical study conducted by the authors in the Moscow State University of Technology and Management (First Cossack University), an analysis of the protest activity of youth (students) in the 2010 s is conducted. The authors rely on a set of methodological approaches and methods of analysis: conceptual, behaviorist, and sociocultural approaches, as well as the network approach aimed at understanding the basic constructs of the digital age and digital communications as a new social reality. The authors develop the method of discourse analysis to demonstrate the protest activism being contingent on the rapidly changing conditions. The modern definition of protest is analyzed. The term protestivity is introduced and its heuristic value is substantiated. The distinction between civic activism and protestivity is drawn. The authors explore the preconditions for the formation of protest: youth lumpenization, deprivation (inconsistency between the increased social expectations of young people and the real possibilities for their realization). The manifestations of youth protestivity in the modern conditions increasingly acquiring the structure of network interaction are studied. It is concluded that the repertoire of youth protestivity in a digital society is modifying. The article demonstrates that positive (constructive) forms of protest activity contribute to the formation of a conventional form of interaction between youth and authorities. Involvement in positive forms of activism stops the natural potential of youth protest. The future largely depends on what status the authorities assign to youth.
\end{abstract}

Keywords: youth, student youth, civic activism, protest, youth protest, digital society, destructive and constructive forms of youth protest activity.

\footnotetext{
* Corresponding author: vipperh@yandex.ru
} 


\section{Introduction}

Young people dramatically react to emotional activators and reflect on the challenges and problems of society expressing their dissatisfaction through various mechanisms including the virtual and game formats. Student youth protest activity has to be examined not only as a negative and destructive process disturbing social and political stability but also as a way of actualization of a pressing social issue.

The problem field. We are examining the problem of protest activity in the 2010s. Over this decade, protest activity has changed both in the form (from street rallies to network communications) and intensity (waves of rise and fall) [1]. Our initial thesis is the distinction between civic activism and protest activity which, in turn, can only be viewed negatively.

Civic activism involves "citizens' conscious and purposeful participation in public and political life to protect, realize, and expand their economic, political, and social interests" [2]. A protest is not only a result of discontent, the discovery of a problem that requires emotional and effective involvement. A protest is a process involving various actions characteristic of different social and age groups: some people repost messages, some go to courts, some help political prisoners, some stand in pickets, and some go to mass actions [3]. The main feature differentiating civic activism and protest activity or protestivity (our term) is that "protest can independently 'produce' political discourse and agenda offering a new language and alternative communication mechanisms" [4]. A protest is a means of influencing the government - "shaking up the authority" - in the interests of civil society".

Protectivity is natural to youth and is essentially a way for new generations to integrate into society through rejecting the values of adults. Young people at the age of 14-25 years old feel the unfairness of the social order especially acutely and express their discontent through various mechanisms: harsh or mild, legal or illegal, positive (constructive) or negative (destructive).

Youth protestivity is characterized by increased emotionality. The problem field of the present study includes the analysis of the main activators of emotions - the problems, events, topics, and factors that serve as signals that stimulate the transition from interest to experience and emotion and from emotion to action. Psychologist C. Izard notes that if a person is interested in an event or phenomenon, "there is a desire to explore the object of interest, to know it, to take part in what is happening, to absorb information, thereby expanding their 'Self', to gain new experiences from interaction with the object that aroused interest" [5: 115].

It is demonstrated that for modern youth including students, political activators are less important than non-political: ecological, social, and value-ethical. Moreover, involvement in the positive forms of activism ensures the emotionality of participation while neutralizing protestivity itself.

Study goals and objectives. The goal of the study is to develop a format of youth activism within the conventional dialogue culture in its positive (constructive) forms and identify the conditions under which these forms can exist and manifest neutralizing the potential of the natural protestivity of youth.

The study objective is to develop a model for the implementation of the obtained results in Russian universities based on the empirical analysis of protest ideas and the ability to form a conventional culture of civic participation conducted among the students of the Moscow State University of Technology and Management (First Cossack University) (Moscow, Russia).

\footnotetext{
* Compared to an earlier understanding of protest as a manifestation of disagreement, dissent, as an opposition activity [6].
} 
What is significant for understanding the "natural" form of youth protestivity is the theory of relative deprivation developed by S. Stouffer, J. Davis, T. Gurr et. al. [7]. This theory explains "why people rebel". When the ideal and real situations are compared, the subjective feeling of discontent regarding one's present emerges and strengthens and is then transferred to various objects: power, state, parents, bosses, "enemies". The subject of deprivation gets involved in some type of protest action seeking to eliminate obstacles to the realization of their initial expectations.

\section{Methods}

In our study, we rely on a set of methodological approaches and methods of analysis [8]: the conceptual approach that begins with the development of the research concept and includes its key features; the behaviorist approach that manifests in the study of activism, protestivity, and other types of behavior of youth as the action of subjects who determine their life position and strategy independently; the sociocultural approach focuses our attention on the development of a format of youth activism within the conventional dialogue culture accounting for the sociocultural and value-ethical nature of the activators of behavior; the network approach focusing on understanding the fundamental constructs of the digital age and digital communication as the new social reality.

We also deploy the method of discourse analysis to demonstrate the contingency of protest activism in rapidly changing conditions. The study combines a theoretical analysis of protest youth as a special social phenomenon and the results of an empirical study conducted in 2019 and 2020 among the students of the Moscow State University of Technology and Management and its branches. The data was collected through an individual survey completed by the study participants on the territory of the buildings of the designated universities. The survey was anonymous. Data processing included entering the primary results into Excel and processing them in a standard way (with the provision of distribution tables of the survey indicators).

\section{Results}

The study design involves measuring the following indicators:

- the attitude towards events in Russian politics and economy;

- the degree of political activism;

- student youth's motives for participation or non-participation in politics;

- the attitudes towards politics and the level of satisfaction with Russian politics;

- the attitude towards the prominent problems of Russian society;

- student youth's attitude toward rallies and demonstrations against the policies of the current government and their participants;

- student youth's readiness to participate in different forms of protest activity.

The general population is represented by students of the head university - the Federal State Educational Institution of Higher Education "Moscow State University of Technology and Management (First Cossack University)" (FSBEI HE "MSUTM (FCU)") including all institutes within it (6,075 people), as well as students studying in its branches (in the cities of Kaliningrad, Meleuz, Rostov-on-Don, Penza, and Omsk (5,871 people).

The prerequisites for the formation of protest including youth lumpenization and deprivation (inconsistency between the increased social expectations of young people and the real possibilities for their realization) were studied [9]. The manifestations of youth protestivity in the modern conditions increasingly acquiring the structure of network 
interaction were also examined. The new forms of the protest movement include the game types (flash mobs) with virtual ways of mobilizing participants and taking active action.

It is crucial to understand the distinction between the harsh (going out to the streets, violent behavior, political extremism) and mild modes of protestivity (comments, likes, petitions, fundraising, online flash mobs). Such mild protestivity can be an expression of young people's desire to give important meanings to their lives: to better the world around them, to protect human rights, to save animals and nature, to preserve cultural sites and historical monuments for future generations. This form of protest activity is not destructive and merges with activism. According to the study results, it is this form that characterizes the political culture of the students of the MSUTM.

\section{Discussion}

The conducted survey allows us to reveal the natural protest potential of the students of the MSUTM and assess their readiness to take part in different types of protest activity that were arranged by an increase in the "degree of protest" from mild to the most extremist:

- thematic concerts, exhibitions, performances, installations;

- web and game forms, flash mobs;

- likes, comments, signing petitions;

- voting against all or following protest motives;

- signing collective protest appeals, petitions;

- allowed forms of protests: rallies, demonstrations, pickets;

- open criticism of the authorities in the media and on the Internet; campaigning against the current government;

- strikes;

- unsanctioned protests (rallies, demonstrations, pickets);

- blocking roads, occupying buildings;

- change of power through mass non-violent protest;

- revolt (violent spontaneous protests against the authorities);

- rebellion (planned mass demonstrations against the existing government to overthrow it).

1. Analyzing the distribution profile of the respondents' evaluations (the percentage of readiness to partake in various forms of protest activity), we can state that, in the minds of student youth, the most acceptable forms of protest activity are: a) signing collective protest appeals and petitions (in case of which the degree of personal involvement is diluted) and b) thematic concerts, exhibitions, performances, installations, and flash mobs. Regarding these forms of activity the respondents expressed the maximum readiness for participation.

Specifically, $16 \%$ of the respondents are "definitely ready" to partake in signing collective protest appeals and petitions and $18.2 \%$ are "definitely ready" to participate in thematic concerts, exhibitions, performances, installations, and flash mobs. The total percentage of those who are to varying degrees willing to participate in signing collective protest appeals and petitions is $30.8 \%$; the total percentage of people to varying degrees willing to participate in thematic concerts, exhibitions, performances, installations, and flash mobs is $47.1 \%$. On the other hand, the profile of the respondents' evaluations of these two forms of activity is characterized by a minimal percentage of the choice of the "categorically not ready to participate" answer option (about $26 \%$ ).

The study shows that around $70 \%$ of the respondents are categorically not ready to participate in the two most extreme forms of protest activity (riot and rebellion).

2. We view the readiness of student youth to take part in protest activity as contingent on the presence of pressing social problems causing deprivation as an inconsistency 
between the desired and actual state of affairs in a person's mind. The earlier the problem is realized and actualized, the more chances there are to make adjustments to resolve the social problem or reduce its severity. Protestivity most often presents a reaction to an activator, a response to a problem that manifests in an especially emotional form in the youth environment. This is the constructive effect of protest activism.

Thus, the protest activity of student youth needs to be examined not only as a negative and destructive process disrupting the stability of social and political life but also as a way of actualizing a pressing social problem [10]. Involvement in the positive forms of activism suppresses the natural potential of youth protestivity.

Figure 1 shows the problems of modern Russia that, according to the survey data, evoke the greatest emotional response from students.

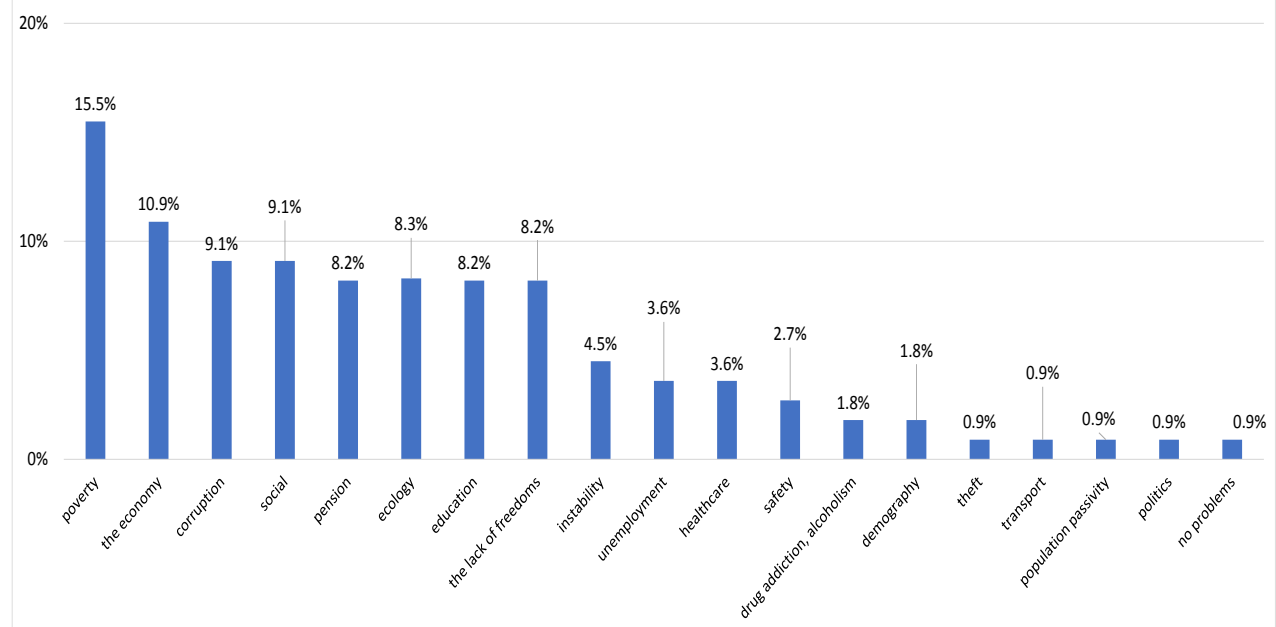

Fig. 1. Prominent problems of the Russian society

The degree of readiness to protest is a certain indicator of the subjective importance of each of the presented problems which is highly important for the governing bodies determining the priorities of the social and economic policy of the Russian Federation at the present stage and for the upcoming future. The first place in terms of importance (the maximum percentage of respondents to varying degrees ready to participate in protests related to this problem) is occupied by problems in the social sphere (non-payment of salaries, scholarships, etc.). It is in relation to problems in the social sphere that $61.5 \%$ of respondents are ready to participate in protest actions with varying degrees of intensity.

Further on, the problems are arranged in the overall rating in the following order:

- problems in the legal sphere (corruption, infringement of rights, etc.) $-56 \%$;

- the local problems of the city of residence (poor buildings, roads, medicine, etc.) $55.5 \%$;

- environmental problems (protection of nature, preservation of an environment that is safe to live in) $-53.5 \%$;

- economic problems (crisis, low living standards of the population) $-50.4 \%$;

- safety problems (crime, terrorist attacks, etc.) $-49.6 \%$.

Protest youth form a certain socio-political agenda associated both with claims against the authorities and with value orientations. A harsh protest strategy of political participation leads to significant costs, confrontation with power structures, and conflicts. On the other hand, protest activity serves as an indicator of distress and includes mechanisms for 
responding to challenges. It can become a platform for developing a conventional culture of interaction between youth and the state.

At the same time, involvement in the positive forms of activism (volunteering, charity, human rights protection, ecoactivism, animal protection, protection of cultural objects, saving historical monuments from barbaric destruction) stops the natural potential of youth protest. This transforms the potent energy of discontent and deprivation into constructive forms that ultimately allow one to engage in dialogue and conventional relationships with the authorities.

\section{Conclusion}

The obtained results provide grounds for a conclusion about the constructive possibilities of youth protest activism within the framework of the conventional dialogue culture.

The development of a youth activism format within the conventional culture involves freedom of expression; involving students in various forms of designing their future; gradual involvement of a significant layer of "indifferent" people in the format of constructive activity; establishing the altruistic value foundations of life.

The role of network communications in the protest activity of student youth is increasing. Virtually all young online users are involved in the process of "digital consensus". As a recommendation for sociologists and psychologists, we suggest accounting for the decentralized and liberal nature of the Internet (organically accepted by the younger generation) when studying youth protests.

In most cases, the protesting student youth does not trust the representatives of the authorities; therefore, their poor interaction with officials is observed. This reduces the likelihood of a functional negotiated solution to problems and fosters resentment. The future of not only the younger generation but also the government itself will depend on what status the government prescribes to student youth and what it sees their role in.

\section{References}

1. E.V. Aralova, T.L. Kashchenko, I.V. Polozhentseva, I.A. Sinitsyna, and G.N. Yulina, Dilemas contemporáneos: Educación, Política y Valores, 7(1), 118 (2019)

2. I.N. Trofimova, Sotsiologicheskie Issledovaniya [Sociological Studies] 4, 72-77 (2015)

3. A. Zakharov, A. Arkhipova, Kak izmenilsia protest [How has protest changed] (2019). Accessed on: December 01, 2020. [Online]. Available: https://www.vedomosti.ru/opinion/articles/2019/09/30/812372-kak-izmenilsya-protest

4. V.V. Petukhov, R.E. Barash, N.N. Sedova, R.V. Petukhov, Vlast' [The Authority], 22(9), 11-19 (2014). Accessed on: December 08, 2020. [Online]. Available: https://www.jour.fnisc.ru/index.php/vlast/article/view/2765

5. C.E. Izard, The Psychology of Emotions (Springer US, New York, 1991)

6. Yu.F. Lukin, Soprotivleniye totalitarizmu, aktivnost' i protest v istorii sovetskogo obshchestva [Resistance to totalitarianism, activity and protest in the history of Soviet society]. Dissertation of Doctor of Historical Sciences (M. V. Lomonosov Pomor State University, Arkhangelsk, 1992)

7. T.R. Gurr, Why Men Rebel (Routledge, Abingdon, 2011)

8. E.V. Brodovskaya, N.A. Tyukov, Vlast' [The Authority], 28(2), 199-204 (2020). https://doi.org/10.31171/vlast.v28i2.7157 
9. I.N. Sycheva, O.V. Chernyshova, T.A. Panteleeva, O.A. Moiseeva, S.A.

Chernyavskaya, S.Y. Khout, International Journal of Economics and Business

Administration, 7(1), 595-606 (2019)

10. O.M. Ivanova, L.M. Bilalova, G.N. Yulina, I.V. Polozhentseva, Dilemas Contemporáneos: Educación, Política y Valores, 7(10), 69 (2019)

11. A.Y. Dombrovskaya, Vlast' [The Authority], 28(2), 51-58 (2020). https://doi.org/10.31171/vlast.v28i2.7134

12. N.N. Sedova, Sotsiologicheskiy Zhurnal [Sociological Journal], 2, 48-71 (2014). https://doi.org/10.19181/socjour.2014.2.495.

13. V.I. Chuprov, Yu.A. Zubok, Monitoring Obshchestvennogo Mneniya: Ekonomicheskie i Sotsial'nye Peremeny, 1(89), 146-166 (2009)

14. A. Vromen, Digital citizenship and political engagement: the challenge from online campaigning and advocacy organisations (Palgrave Macmillan, London, 2017) 